International Journal of Mechanical Engineering and Technology (IJMET)

Volume 11, Issue 10, October 2020, pp. 13-18, Article ID: IJMET_11_10_002

Available online at https://iaeme.com/Home/issue/IJMET?Volume $=11 \&$ Issue $=10$

ISSN Print: 0976-6340 and ISSN Online: 0976-6359

DOI: https://doi.org/10.34218/IJMET.11.10.2020.002

(C) IAEME Publication

Scope Database Indexed

\title{
SCHOOL VAN MOUNTED SANITIZING MACHINE FOR STUDENT'S SAFETY
}

\author{
Vedant Joshi \\ Science Technology Engineering Mathematics (STEM) Trainer/Faculty, \\ India STEM foundation, Gurgaon-122001, Haryana, India
}

\begin{abstract}
In India usually students go to school by a bus or a van. But in this corona virus pandemic, one of the reason for parents to not send their child to school would be the safety during the travel, both while going to school and coming back to home from school. This is where Van mounted sanitizing machine (VMSM) can help schools to get reopened. The sanitizing sprayers are going to be mounted outside the van. The VMSM system can be controlled from inside the van so that driver can reduce the wastage of time, as they already have a time consuming task of sanitizing each student properly. Instead of using costly hydraulic pump to create high pressure, this machine will work on the principal of spray paint machine. Since this machine will be mounted outside the van, it will not only sanitize students but will give satisfaction to parents also, that not only their child is getting sanitized but other children are already sanitized before sitting inside van. The machine is designed by considering cost effectiveness. So that the van drives, coming from middle class background can buy it.
\end{abstract}

Keywords: Mountable sanitizing machine, quad spray system, low cost, easy to manufacture.

Cite this Article: Vedant Joshi, School Van Mounted Sanitizing Machine for Student's Safety. International Journal of Mechanical Engineering and Technology. 11(10), 2020, pp. 13-18.

https://iaeme.com/Home/issue/IJMET?Volume $=11 \&$ Issue $=10$

\section{INTRODUCTION}

In India usually students go school by a bus or a van. Since inside the residential area buses cannot turn properly, therefore vans are typically used to get a large percentage of students. The school van mounting sanitizer machine is something which can be used to sanitize students before sitting into van. Every parent want their children to be safe, because of that they are not going to take any risk when it comes to life of their child. May be because of this they will not send their child to school for months and even if they will, they will try to drop them by their own vehicle. Now dropping children by own vehicle will create a chaos in timing of parents and children, secondly it will create huge traffic around schools. So vans 
and busses are a big need of many schools in today's time. And therefore, instead of removing vehicle, it is better to innovate or change them according to current scenario.

So the school van mountable sanitizer is going to be something which will give hope to every parent that all children sat before their child and after their child are properly sanitized. This sanitizer is totally made by considering cost and availability. Since in India school van owners cannot buy a fully automatic sanitizing machine therefore this mountable sanitizer is going to be work mostly using human power. The major advantage of simple and low cost parts is that they can be easily available. Being easily available means the machine can be easily replicate, which is a good sign, since this corona pandemic time is not going to pass very soon, it is better to either make or find parts around us and try to make things work again on same pace, so that economy of whole world can come to a better shape again. There are 3 main parts in VMSM machine - Sanitizer tank (B), quad spray system (C), Pressure pump (F). Quad spray system is attached with two supporting parts - Connecting square tube (D), Supporting square tube. Sanitizer tank is a noncorrosive high pressure tank. The tank takes air from F3 pipe and create pressure in tank. Tank keep the pressure high using a ball check valve. High pressure result in removing sanitizer out of the tank through B3 tube. B3 is connected with $\mathrm{C} 5$ tube using a flexible rubber pipe. High pressure sanitizer then distributed in four C3 pipes equally, which eventually come out of C2 nozzles. Due to very thin opening of nozzles, sanitizing liquid get atomize and spread in all four sides equally. Pressure pump is a customizable part of this machine. Customizable part means that the type of part going to be used by car owner can be depend upon their budget, human strength, usage and availability. Therefore both electric powered and human powered pressure pump can be used in VMSM. The position of pressure pump can also be differ according to model of van, type of usage and ease of driver. The two main position of pressure pump can be 1. As shown in diagram1, if required, someone other than driver can also operate pump at this position. 2. Pump can also be place near the clutch-break system of car. This will save time of driver.

Part C, D and E become a one big pin joint part after getting connected. Part $\mathrm{C}$ is a spray system whereas part $\mathrm{D}$ is another half of part $\mathrm{C}$. Part $\mathrm{C}$ is divided into two part so that after usage, driver can put it horizontally on the pressure tank. Part E is to support load of part C's frame. Strength test of part $\mathrm{E}$ is given in analysis below.

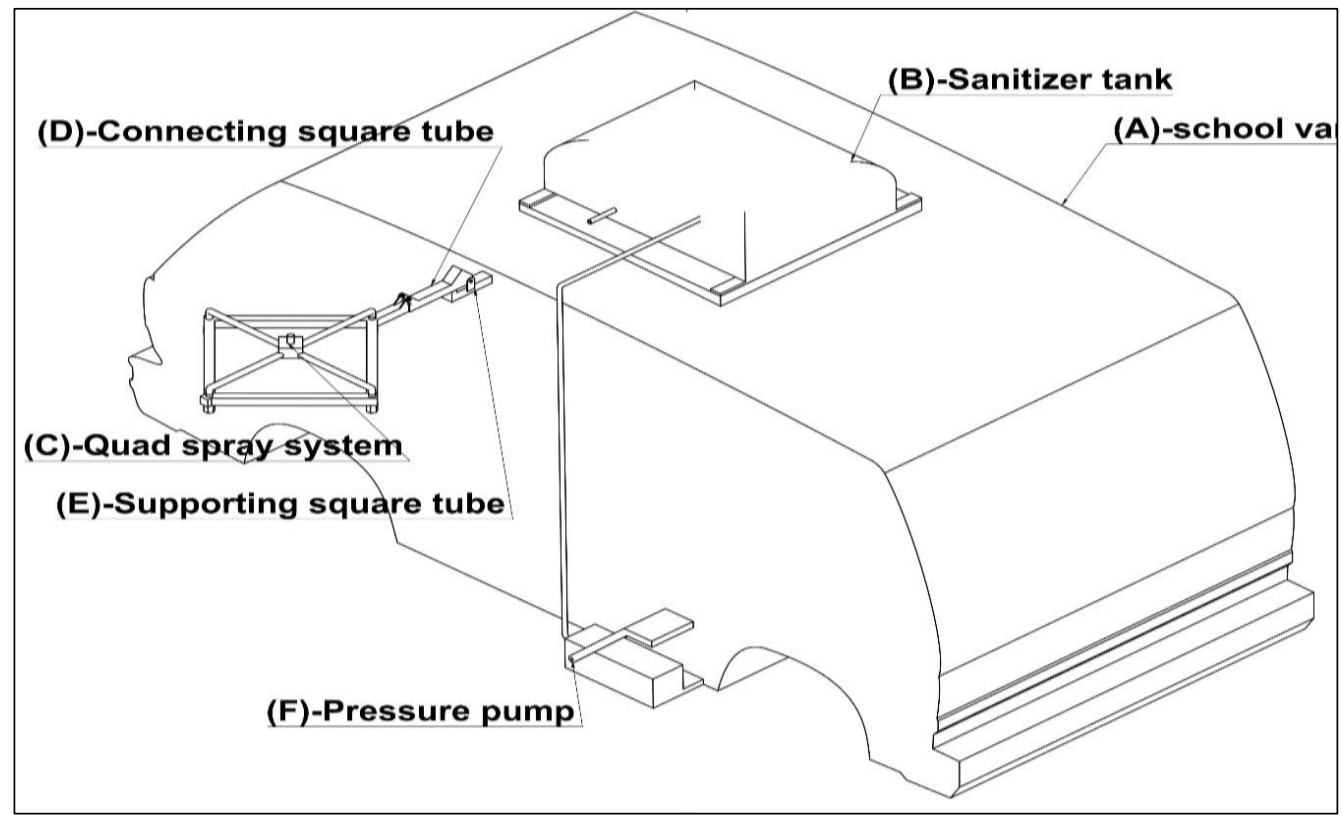

Figure 1 


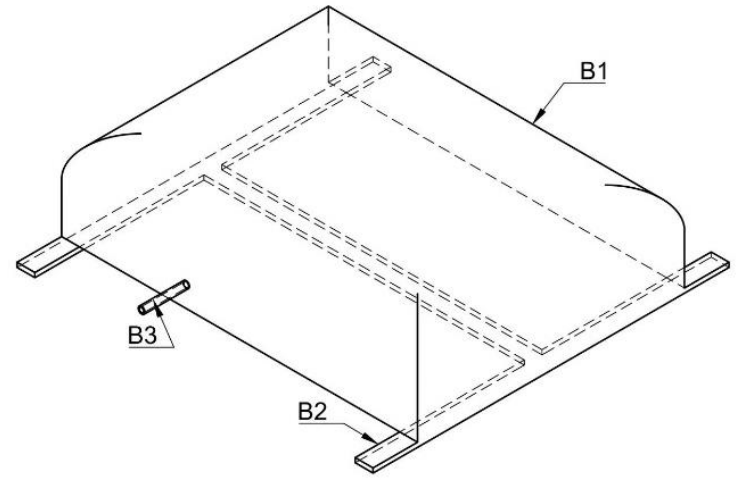

Figure 2

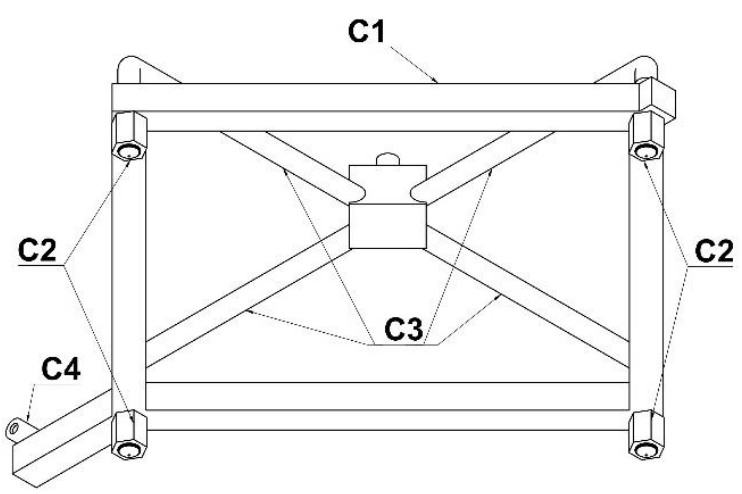

Figure 3 (Bottom View)

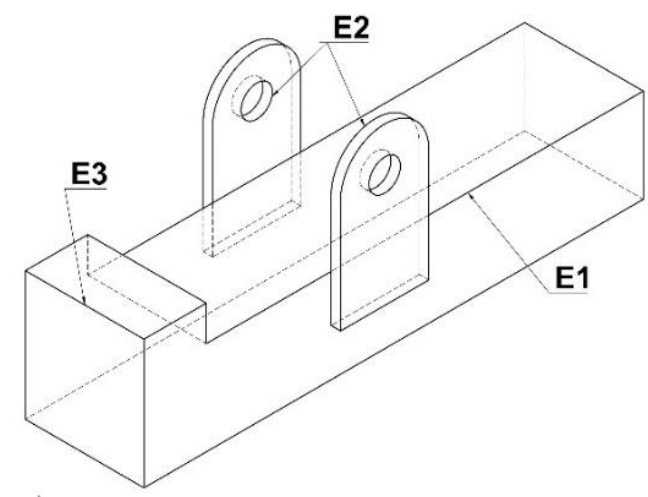

Figure 5

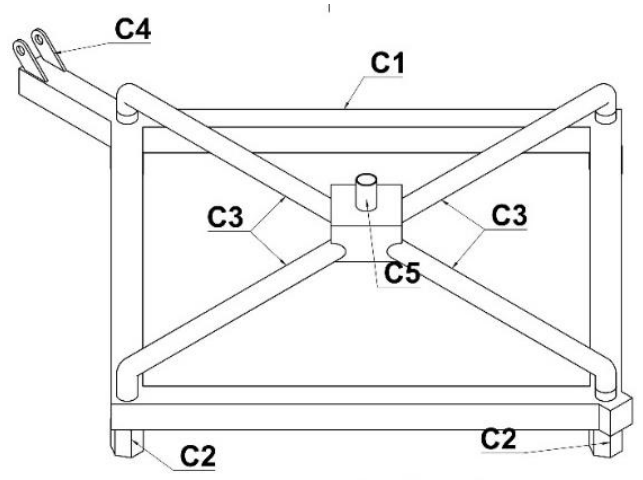

Figure 3 (Top View)

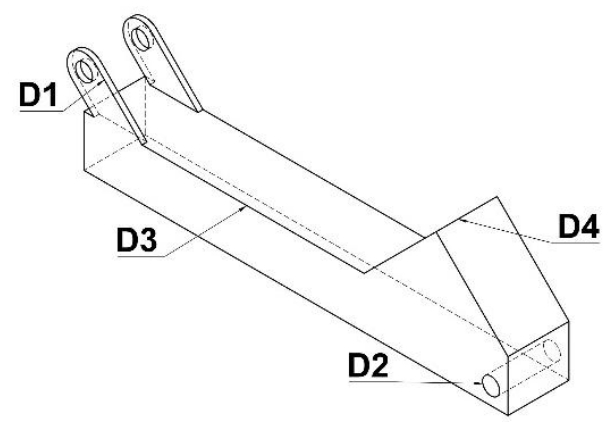

Figure 4

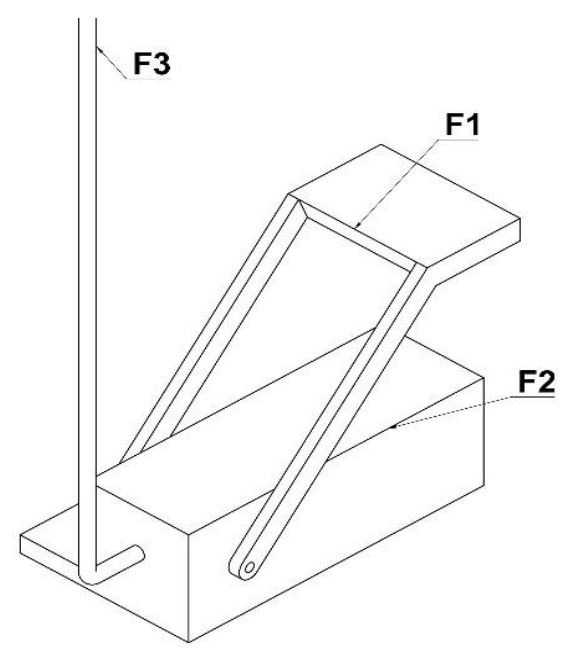

Figure 6

\section{STRUCTURAL ANALYSIS}

\subsection{Materials}

\begin{tabular}{|l|l|l|}
\hline \multicolumn{1}{|c|}{ Part E:1 } & \multicolumn{1}{|c|}{ Steel, Mild } & \multicolumn{1}{c|}{ Yield } \\
\hline Part D:1 & Aluminum - High- & Yield \\
\hline Part & Aluminum - High- & Yield \\
\hline Part & Aluminum - High- & Yield \\
\hline Part & Aluminum - High- & Yield \\
\hline Part & Aluminum - High- & Yield \\
\hline
\end{tabular}




\begin{tabular}{|l|l|l|}
\hline Part & Aluminum - High- & Yield \\
\hline Part A:1 & Steel & Yield \\
\hline Part & Aluminum - High- & Yield \\
\hline Part & Aluminum - High- & Yield \\
\hline Part B:1 & Galvanized Steel & Yield \\
\hline
\end{tabular}

\subsection{Loads}

\subsubsection{Gravity}

\begin{tabular}{|l|l|}
\hline \multicolumn{1}{|c|}{ Type } & \multicolumn{1}{c|}{ Gravity } \\
\hline Magnitude & $9.807 \mathrm{~m} / \mathrm{s}^{\wedge} 2$ \\
\hline X Value & $-2.411 \mathrm{E}-15 \mathrm{~m} / \mathrm{s}^{\wedge} 2$ \\
\hline Y Value & $-9.807 \mathrm{~m} / \mathrm{s}^{\wedge} 2$ \\
\hline$Z$ Value & $-2.178 \mathrm{E}-15 \mathrm{~m} / \mathrm{s}^{\wedge} 2$ \\
\hline
\end{tabular}

\subsubsection{Force}

\begin{tabular}{|l|l|}
\hline \multicolumn{1}{|c|}{ Type } & \multicolumn{1}{c|}{ Force } \\
\hline Magnitude & $29.5 \mathrm{~N}$ \\
\hline X Value & $0 \mathrm{~N}$ \\
\hline Y Value & $-29.5 \mathrm{~N}$ \\
\hline Z Value & $0 \mathrm{~N}$ \\
\hline Force Per Entity & No \\
\hline
\end{tabular}

\subsubsection{Safety Factor (Per Body) $0 \square \square$}

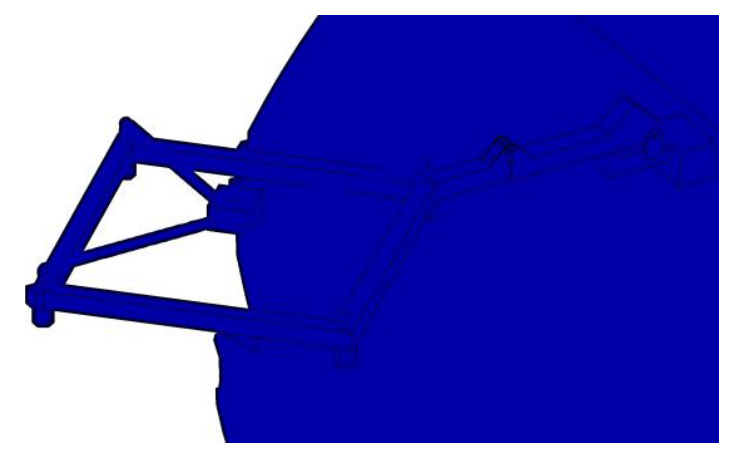

Figure 7

\section{RESULTS}

\subsection{Result Summar (7)}

\begin{tabular}{|l|l|l|}
\hline \multicolumn{1}{|c|}{ Name } & \multicolumn{1}{c|}{ Minimum } & \multicolumn{1}{l|}{ Maximum } \\
\hline Safety Factor & \multicolumn{2}{|l|}{} \\
\hline Safety Factor (Per Body) & 15 & 15 \\
\hline Stress & $1.236 \mathrm{E}-19 \mathrm{MPa}$ & $0.8317 \mathrm{MPa}$ \\
\hline Von Mises & $-0.0757 \mathrm{MPa}$ & $0.8239 \mathrm{MPa}$ \\
\hline 1st Principal & $-0.2613 \mathrm{MPa}$ & $0.08624 \mathrm{MPa}$ \\
\hline 3rd Principal & $-0.2591 \mathrm{MPa}$ & $0.2662 \mathrm{MPa}$ \\
\hline Normal XX & $-0.2014 \mathrm{MPa}$ & $0.7576 \mathrm{MPa}$ \\
\hline Normal YY & $-0.1093 \mathrm{MPa}$ & $0.1419 \mathrm{MPa}$ \\
\hline Normal ZZ & $-0.1399 \mathrm{MPa}$ & $0.2926 \mathrm{MPa}$ \\
\hline Shear XY & $-0.1684 \mathrm{MPa}$ & $0.1862 \mathrm{MPa}$ \\
\hline Shear YZ & \multicolumn{2}{|l}{} \\
\hline
\end{tabular}




\begin{tabular}{|c|c|c|}
\hline Shear ZX & $-\mathbf{- 0 . 0 8 7 0 7} \mathrm{MPa}$ & $0.1309 \mathrm{MPa}$ \\
\hline \multicolumn{3}{|l|}{ Displacement } \\
\hline Total & $0 \mathrm{~mm}$ & $0.005811 \mathrm{~mm}$ \\
\hline $\mathrm{X}$ & $-2.105 \mathrm{E}-04 \mathrm{~mm}$ & $1.164 \mathrm{E}-04 \mathrm{~mm}$ \\
\hline $\mathrm{Y}$ & $-0.004149 \mathrm{~mm}$ & $5.935 \mathrm{E}-05 \mathrm{~mm}$ \\
\hline $\mathrm{Z}$ & -2.019E-04 mm & $0.004244 \mathrm{~mm}$ \\
\hline \multicolumn{3}{|c|}{ Reaction Force } \\
\hline Total & $0 \mathrm{~N}$ & $465.2 \mathrm{~N}$ \\
\hline $\mathrm{X}$ & $-73.02 \mathrm{~N}$ & $74.64 \mathrm{~N}$ \\
\hline $\mathrm{Y}$ & $-18.84 \mathrm{~N}$ & $453.2 \mathrm{~N}$ \\
\hline $\mathrm{Z}$ & $-125.4 \mathrm{~N}$ & $102.2 \mathrm{~N}$ \\
\hline \multicolumn{3}{|l|}{ Strain } \\
\hline Equivalent & 0 & 4.775E-06 \\
\hline 1st Principal & $-2.506 \mathrm{E}-11$ & $5.23 \mathrm{E}-06$ \\
\hline 3rd Principal & -3.499E-06 & $3.164 \mathrm{E}-08$ \\
\hline Normal XX & $-1.247 \mathrm{E}-06$ & $1.185 \mathrm{E}-06$ \\
\hline Normal YY & $-1.875 \mathrm{E}-06$ & $3.378 \mathrm{E}-06$ \\
\hline Normal ZZ & -1.4E-06 & $1.2 \mathrm{E}-06$ \\
\hline Shear XY & $-3.327 \mathrm{E}-06$ & 3.391E-06 \\
\hline Shear YZ & -2.789E-06 & 2.874E-06 \\
\hline Shear ZX & -1.409E-06 & $1.518 \mathrm{E}-06$ \\
\hline \multicolumn{3}{|c|}{ Contact Pressure } \\
\hline Total & $0 \mathrm{MPa}$ & $0.0558 \mathrm{MPa}$ \\
\hline $\mathrm{X}$ & $-0.021 \mathrm{MPa}$ & $0.01873 \mathrm{MPa}$ \\
\hline $\mathrm{Y}$ & $-0.05547 \mathrm{MPa}$ & $0.02024 \mathrm{MPa}$ \\
\hline $\mathrm{Z}$ & $-0.01343 \mathrm{MPa}$ & $0.01102 \mathrm{MPa}$ \\
\hline
\end{tabular}

\subsection{Stress $-[\mathrm{MPa}] 0 \mathbb{0} \quad \mathbb{0 . 8 3 1 7}$}

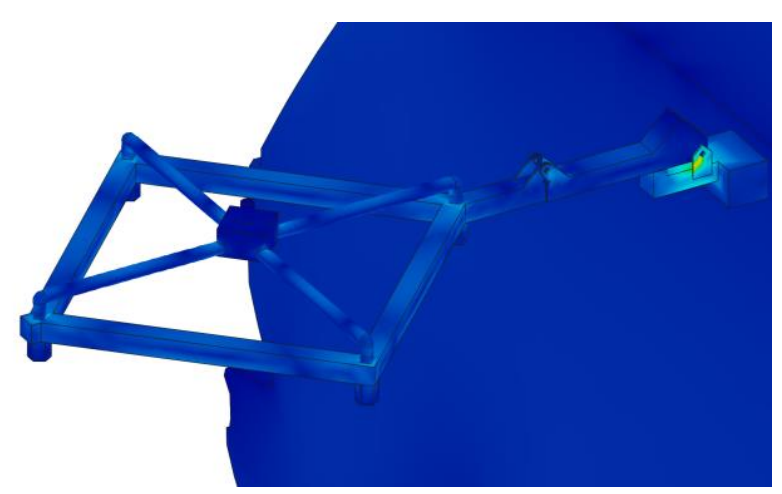

Figure 8 


\subsection{Displacement - $[\mathrm{mm}] 0 \mathrm{0} \quad 0.005811$}

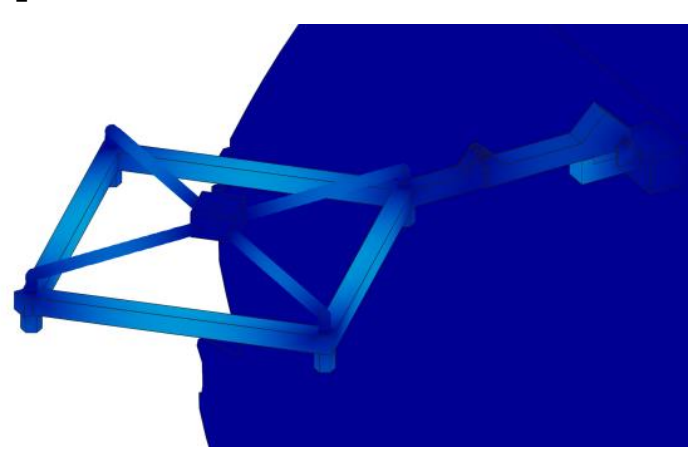

Figure 9

\subsection{Pressure (output)}

[psi] 43 to 51

Medium - Atomizing nozzle

\subsection{Pressure (input)}

[psi] 40 to 50

Medium - Foot pump/ electric water pump

\section{CASE STUDY}

In the present study, strength of frame and pressure output of pressure pump is determined. Sprayer frame is showing displacement and stress in safe region and the values of output pressure obtained in study of foot pump is determined to be very close to required pressure of nozzle (to create atomized particles). Therefore, a foot/electric pump generating 40psi pressure and set of 4 nozzles (welded on a foldable aluminum frame) is sufficient to sanitize a child before entering school van.

\section{CONCLUSION}

From all the above results and designs, we can say that this model of van mounted spray system is safe, feasible and suitable for any van model in market. Its foldable design will protect van from electric wires and the alternative of using foot pump will make it cheap for drivers who can not afford it. Most importantly it can help schools to reopen sooner and in safer way.

\section{REFERENCES}

[1] David Roylance, (2008), "Mechanical Properties of Materials", p. 55-71.

[2] Peck, B., and Sigurdson, L.W., (1994), "The Three-Dimensional Vortex Structure of an Impacting Water Drop,” Phys. Fluids, 6(2) (Part 1), p. 564.

[3] R.S Khurmi, (2000), "Hydraulics, Fluid Mechanics and Hydraulic Mechanics", p. 270

[4] Gaurav Verma, (2018), “Autodesk Fusion 360 Book”, $2^{\text {nd }}$ edition 